Researches on Crustacea No. 6 (1974)

Carcinological Society of Japan

c/o Odawara Carcinological Museum

Azabu-Juban 3-11, Minatoku, Tokyo

\title{
エボシガイを付着したスナガニのメガロパについて
}

〔插図 2, 表 1〕

村岡 健 作

（神奈川県立博物館）

\section{MEGALOPA OF OCYPODA, CARRYING STALKED BARNACLE ON ITS BACK}

\author{
Kensaku MURAOKA \\ (Kanagawa Prefectural Museum, Yokohama)
}

筆者はメガロパの背甲にコスジエボシ Conchoderma virgatum hunteri (OWEN)が着生し, さらにそのエボシガイにヒドロ虫類が付着した標本を採集した。

カ二類の体表にはいろいろな動物が付着もしくは固着して生活していることは上く知ら れているが, メガロパに他の動物が着生した例は稀と思われるので,ここに写真を付して 紹介する。

Table 1. Size and number of megalopa and barnacle

\begin{tabular}{c|c|c|c|c}
\hline $\begin{array}{c}\text { Megalopa } \\
\text { Number }\end{array}$ & $\begin{array}{c}\text { Length of } \\
\text { carapace }(\mathrm{mm})\end{array}$ & $\begin{array}{c}\text { Width of } \\
\text { carapace }(\mathrm{mm})\end{array}$ & $\begin{array}{c}\text { Number of } \\
\text { attached barnacle }\end{array}$ & $\begin{array}{c}\text { Size of } \\
\text { barnacle }(\mathrm{mm})\end{array}$ \\
\hline \hline No. 1 & 5.5 & 4.7 & 1 & 5.5 \\
No. 2 & 5.9 & 4.8 & 3 & $0.9,3.0,4.5$ \\
No. 3 & 5.7 & 4.8 & 1 & 2.9 \\
No. 4 & 5.5 & 4.8 & 1 & 1.0 \\
No. 5 & 5.7 & 4.7 & 1 & 5.6 \\
\hline
\end{tabular}

コスジエボシが着生していたメガロパは 1973 年 7 月 31 日, 三重県紀伊長島の海野部落 の漁港で夜間採集したものである。これらのメガロパはいずれもスナガニ Ocypoda stimpsoni ORTMANNで, 43 個体中に 5 個体着生し, 大きさは甲長 5.5 5.9 mm, 甲幅 $4.7 \sim 4.8 \mathrm{~mm}$ で あった(Table 1 )。

着生していたコスジエボシはメガロパの背面にのみ認められ，その背甲に認められた個 体数は 3 個体着生していたものが最高であった（Fig. 1)。

コスジエボシは印度洋，マライ諸島および日本に産し，本邦では相模湾，和歌山県瀬戸， 土佐湾で採れ, 大きさは頭状部の長さ $20 \mathrm{~mm}$ 以下で, 通常 $6 \sim 10 \mathrm{~mm}$ 位で, ウミへビや夕 

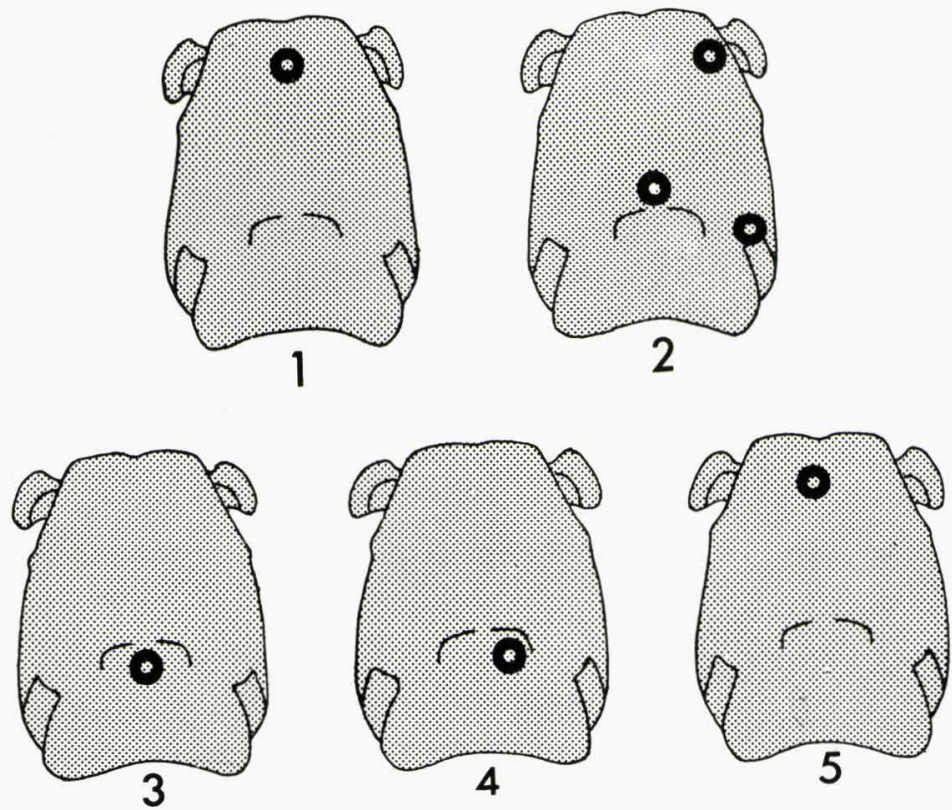

Fig. 1. Spots show the location of stalked barnacles attached to the megalopa, Ocypoda stimpsoni.

イワンガザミの体表に着生していることが知られている（内海(弘) 1937)。

メガロパに着生していたコスジエボシの大きさは最大のもので全長 $5.6 \mathrm{~mm}$ 位であった。 生時は全体茶褐色で, 外皮は薄く, 殼板は縁辺に認められた。またこのコスジエボシの表 面には小形のヒドロ虫類が付着していた個体も認められた (Fig. 2 )。

本邦産のスナガニのヅエアからメガロパ，そして第 1 稚蟹に変態するまで飼育し，観察 した報告はないが，アメリカ産の Ocypoda quadrata (FABRICIUS) を用いて, 卵から䣙化し たゾエア，そしてメガロパまで飼育した報告はある（DIAZ \& COSTLOW, 1972）。

それによれば,メガロパに達するまでの期間は最低 34 日間で,ゾエアは 5 期確認されてい る。ゾエアから変態したメガロパは 2 日以内に死亡してしまったため, 第 1 稚蟹に達する までの日数については観察されていない。

本邦産のスナガニのメガロパは夏から秋にかけて最も多く出現し, 日中は浅海の海底で すごし，夜間は表層に浮遊していることもある。特に夜間集魚灯のような明るい光に集ま る習性をもっている。このメガロパは沖合で一定期間遊泳した後, 砂浜に漂着し, そこで 脱皮し，稚蟹に変態するものと思われる。

筆者は紀伊長島で採集したメガロパのうち， 5 個体(いずれもコスジエボシを着生して いないもの)をシャーレに砂を敷き, 海水を浸して飼育したところ, 3 日以内に 3 個体が稚蟹 に変態した。残りの 2 個体は日数も長びき, 途中で死亡してしまったが, 飼育条件さえ整えば かなりの個体が早期に脱皮するものと思われる。またメがロパが得られた付近の砂浜で, ス十 


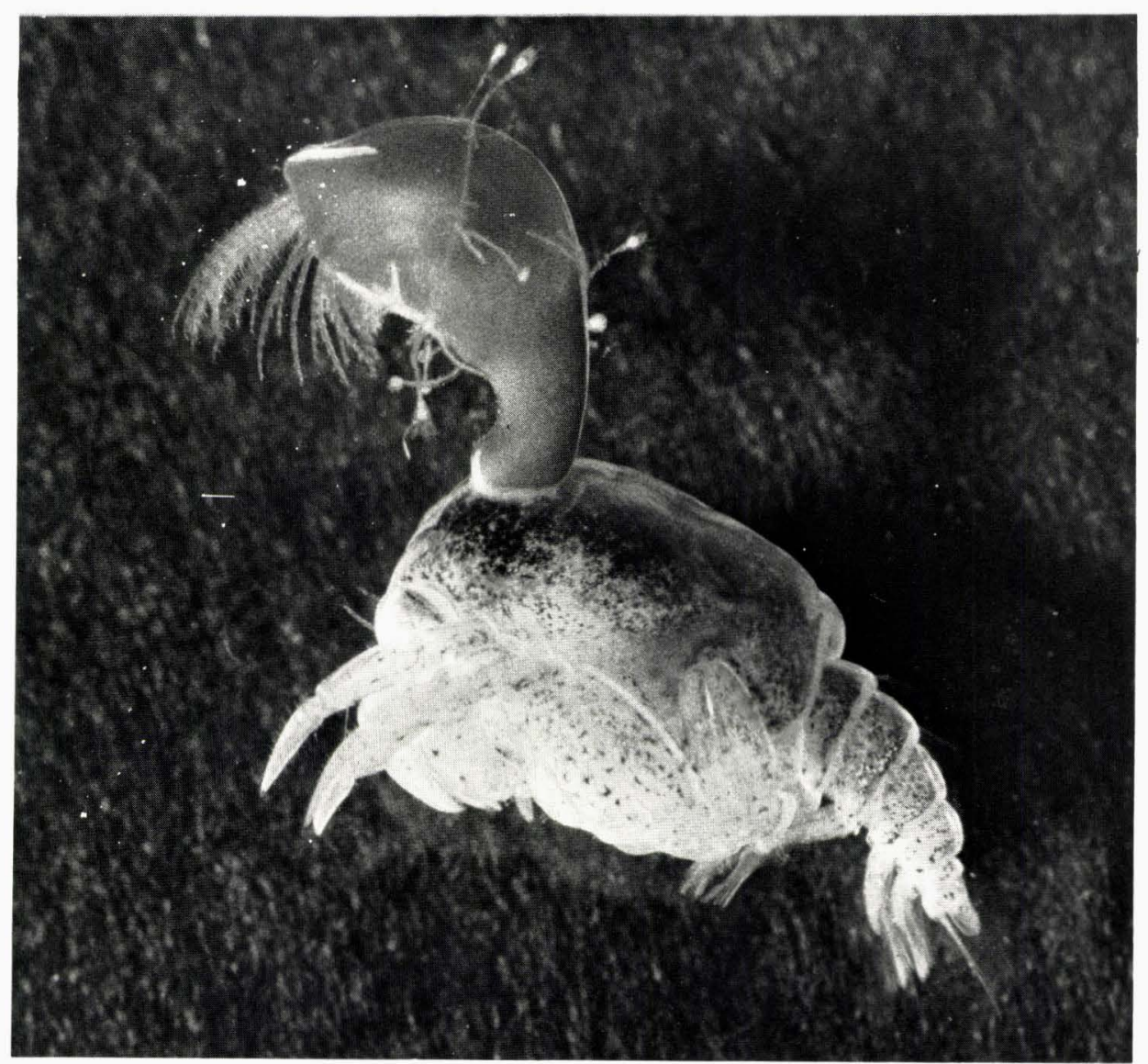

Fig. 2. Megalopa of Ocypoda stimpsoni, carrying stalked barnacle, Conchoderma virgatum hunteri (OWEN) on its back. The barnacle also carrying a mass of Hydrozoa.

ガニの生息状況を調查したところ，第 1 稚蟹期，もしくはそれに近いステージの大きさの カニ 5 個体 (甲長 $5.0-6.0 \mathrm{~mm}$ ) を採集することができた。

これらのことから，ゾエアから変態したメがロパが稚蟹に変態するまで，それほど長期 間かかるとは思われないし，またコスジエボシについてもその大きさから推定して，変態 直後のメガロパに付着したとも考えられる。ただし，スナガニおよびコスジエボシのいず れについても生活史は明らかでなく, 今後観察してみる必要がある。さらにコスジエボシ を付着したメがロパが脱皮し，稚蟹に変態するかどうかも明らかではない。

本文をまとめるにあたって, 御懇篤なる御指導を賜った甲颉類学会長酒井恒博士に厚く 謝意を表するとともに，コスジエボシについての同定ならびに御教示いただいた前京都大 学付属瀬戸臨海実験所長内海富士夫博士に深く感謝申し上げる。また多大なる御協力をい ただいた三重県立松阪高校佐波征機氏および神奈川県立三浦臨海学園佐藤晋氏，ならびに 横浜国大教育学部鈴木博氏に厚く御礼申しあげる。 


\section{文献}

荒川 好 満, 1963. タカアシガニの性行動について. 甲殼類の研究 1:41-46.

Diaz, H. \& Costlow, J. D., 1972. Larval development of Ocypoda quadrata (Brachyura : Crustacea) under laboratory conditions. Marine Biology $15: 120-131$.

村 岡 健 作, 1972. スナガニ科 Ocypoda 属のメガロパについて. 神奈川博研報 $5: 11-18$.

酒 井 恒, 1965. 相模湾産蟹類. 丸善. 東京.

内田享他，1965。新日本動物図鑑(中). 北隆館. 東京.

内海(弘)冨士夫, 1937. 日本動物分類, 9( 5 ). 三省堂. 東京.

内 海 冨士夫, 1955. 日本産蔓脚類の研究, III生態的事項. 日本生物地理 16-19： 124-134. 